\title{
Article
}

\section{Towards a Digital Approach to the Listening to Ancient Places}

\author{
Angela Bellia
}

check for

updates

Citation: Bellia, A. Towards a Digita Approach to the Listening to Ancient Places. Heritage 2021, 4, 2470-2480. https://doi.org/10.3390/heritage 4030139

Academic Editor: Spyros Vosinakis

Received: 31 August 2021

Accepted: 13 September 2021

Published: 15 September 2021

Publisher's Note: MDPI stays neutral with regard to jurisdictional claims in published maps and institutional affiliations.

Copyright: (C) 2021 by the author. Licensee MDPI, Basel, Switzerland. This article is an open access article distributed under the terms and conditions of the Creative Commons Attribution (CC BY) license (https:/ / creativecommons.org/licenses/by/ $4.0 /)$.
Institute of Heritage Science, National Research Council of Italy, 80134 Napoli, Italy; angela.bellia@ispc.cnr.it

\begin{abstract}
This paper aims to investigate digital heritage and acoustical techniques for exploring sonic heritage of archaeological sites and performative spaces. Through the analysis of case studies in Greece and in Italy, this paper intends to highlight a new approach to the development of the relationship between space, sound, and environment and a novel method in deciphering the sonic heritage of ancient spaces thanks to digital technology.
\end{abstract}

Keywords: soundscape archaeology; archaeoacoustics; sensory archaeology; digital sound studies

\section{Introduction}

As something that does not tend to leave direct material traces, sound is not often considered in the archaeological field. However, the relationship between sound and the spaces where life took place in the ancient world is a fundamental aspect of understanding the past. Today, this relationship can be investigated using a new approach in the study of material evidence through technology [1]. If we consider sound as an essential component of spaces and places of religious, social, and daily life activities, it seems surprising that important public spaces in antiquity, such as sacred or theatrical ones, were studied almost exclusively with a focus on their visual aspects [2]. Disregarding the function and role of sound in these places has hitherto prevented a broader understanding of how individuals or groups of individuals may have manifested and experienced their identity and status in the environment and soundscape that surrounded them [3].

Numerous studies have been dedicated to the Greek architectural heritage, especially to places of worship and of performances as ancient theatres. Such studies generally focus on the visual and geometrical dimensions. However, recent researches reveal the importance of multisensory strategies to communicate with the divine and during ritual actions in a performative context. Hence, it appears important to investigate the role of sound within such worship and performative spaces.

Through an approach that aims to recognise and investigate the religious and public spaces of the past as "embodied spaces" and "sensory artefacts" [4,5], we can raise hypotheses on the sound experience in the ancient world and on the complex relationship between spaces and social interactions, making use of the potential provided by the application of 3D technology to virtual acoustics. Furthermore, taking into account sound features and the way sound was propagated in spaces, 3D technology applied to virtual acoustics can provide a broader perspective on the use of spaces in the past, allowing us to explore the connection between auditory space and acoustic space [6] and opening up new scenarios in research. Taking into account the interweaving of relationships between sound and places, space, and the body as well as the relationships between sound and multisensory interaction in a virtual environment, it will be possible to provide new tools for analysis and evaluation of sonic heritage as a further instrument of knowledge of the past [7].

\section{Current Approaches and Methods}

In the current scientific debate on these issues, new approaches and methods related to the use of technology and virtual acoustic analysis of archaeological sites have been fundamental in providing useful data for interpreting the sonic world of the past. In 
terms of the research carried out by some European researchers, the survey has focused on a number of crucial issues. Firstly, research has been carried out by researchers from different disciplinary fields who focused on understanding the relationship between sound space and archaeological space and on how sound could influence the cultural, religious, and social aspects of the ancient world. Moreover, researchers focused on analysing the acoustics and sound qualities of ancient spaces and how their sonic features could influence the auditory experience in a given place. In addition, the performative spaces of the pastin many cases, in close relationship with religious buildings-have been investigated in relationship with the sound qualities of the natural environment in which they were immersed in order to explore how the surrounding soundscape [8] may have influenced religious experiences in antiquity. Finally, the contribution of European researchers to this developing field of study has provided many solutions with regard to 3D reconstructions of buildings and the auralisation of sound in the related spaces. These studies made it possible to propose new hypotheses on how sounds were perceived in ancient societies by individuals who, as listeners or as participants in social events, were the protagonists of performances that took place in those locations [9].

It worth noting that research has been conducted by researchers and their research groups who, through an interdisciplinary and multidisciplinary (and sometimes transdisciplinary) approach, analysed the acoustic and sound features of important archaeological sites in Greece and Italy through virtual acoustic analysis as well as through the 3D reconstruction of spaces and musical instruments in order to reproduce ancient sounds [10,11]. Thanks to their work, new tools for exploring soundscapes of the ancient world that also take into account sensory aspects have emerged. It is a sonic heritage that can further reveal aspects of life in the past and of the sound environment in which these sounds were created: thanks to the use of special software, which allows us to investigate research themes never previously addressed, new scenarios on soundscape studies, with the ancient world as the object of investigation, can be opened up [12].

Within this framework, this paper will explore the spatial dimension of sound in archaeological spaces and the relationship with their intangible aspects; the focus is not only on hearing but an interrelationship of the senses. Using the sound analysis of a performative space as a key to decipher cultural and societal characteristics, the study of ancient performative spaces is not only pivotal to our understanding of physical sonic characteristics of extant buildings, but it also allows us to speculate on how they were used by past societies for sound and sensory experiences. This approach will allow us to recover the lost intangible heritage of archaeological spaces' acoustics through acoustic reconstruction and to assess whether these buildings were built in precise places for their sonic qualities.

\section{Sonic Heritage in Archaeological Sites: Two Case Studies}

Taking into consideration two case studies that aim to enhance our knowledge on the role of sounds in archaeological contexts that are diverse in space and in time, we will analyse how this research is in line with recent developments in archaeology over the past few decades, particularly the interest in new approaches to understanding how ancient people experienced their surroundings. Given that sound has always been an omnipresent component of human experience, recent trends in archaeological inquiry have analysed the importance of acoustics, instruments, and what was heard in the past, taking into consideration that it is possible to ascribe cultural meanings to sonic experiences and that sounds have played important functions in quotidian life. Moreover, current research approaches to archaeoacoustics, soundscapes, and archaeomusicology have highlighted how new sonic hypotheses could be explored thanks especially to the use of technology in these research fields, as has emerged from the first case study in Cristina Manzetti's work [13]. Her research is a study dedicated to the Roman theatre southwest of the sanctuary of Apollo Pizio in Gortyna, a building able to accommodate up to 2000 spectators, which was constructed in the 2nd c. BCE in an area probably already devoted to performances and theatrical 
activities in the Greek age. Her research was carried out at the Laboratory of Geophysical Satellite-Remote Sensing and Archaeo Environment at the Institute for Mediterranean Studies and the Foundation of Research and Technology Hellas in Rethymno (Crete). This survey aimed to understand what types of performances could have taken place in the Roman theatre through the analysis of its acoustic qualities.

Manzetti began by raising some issues. The first concerned the type of sound events that could have taken place in the theatre and whether, due to its acoustic characteristics, it was more suitable for listening to music or for outdoor public speeches. Closely connected to the first, the second issue concerned the assessment of a correspondence between written sources (which recall music and sports competitions related to the celebrations of Apollo Pitius) and a possible performance of these competitions in the theatrical area related to the sanctuary of the divinity in Gortyna. In order to address these issues, she carried out a virtual acoustic analysis, taking into account some limitations that she might encounter: first of all, the state of preservation of the theatre, which made the assessment and acoustic analysis on the site complex. Therefore, it was necessary to build a 3D model of the monument (Figure 1) [14] using software suitable to calculate the acoustic features and to evaluate the behaviour of sound in a virtual environment.

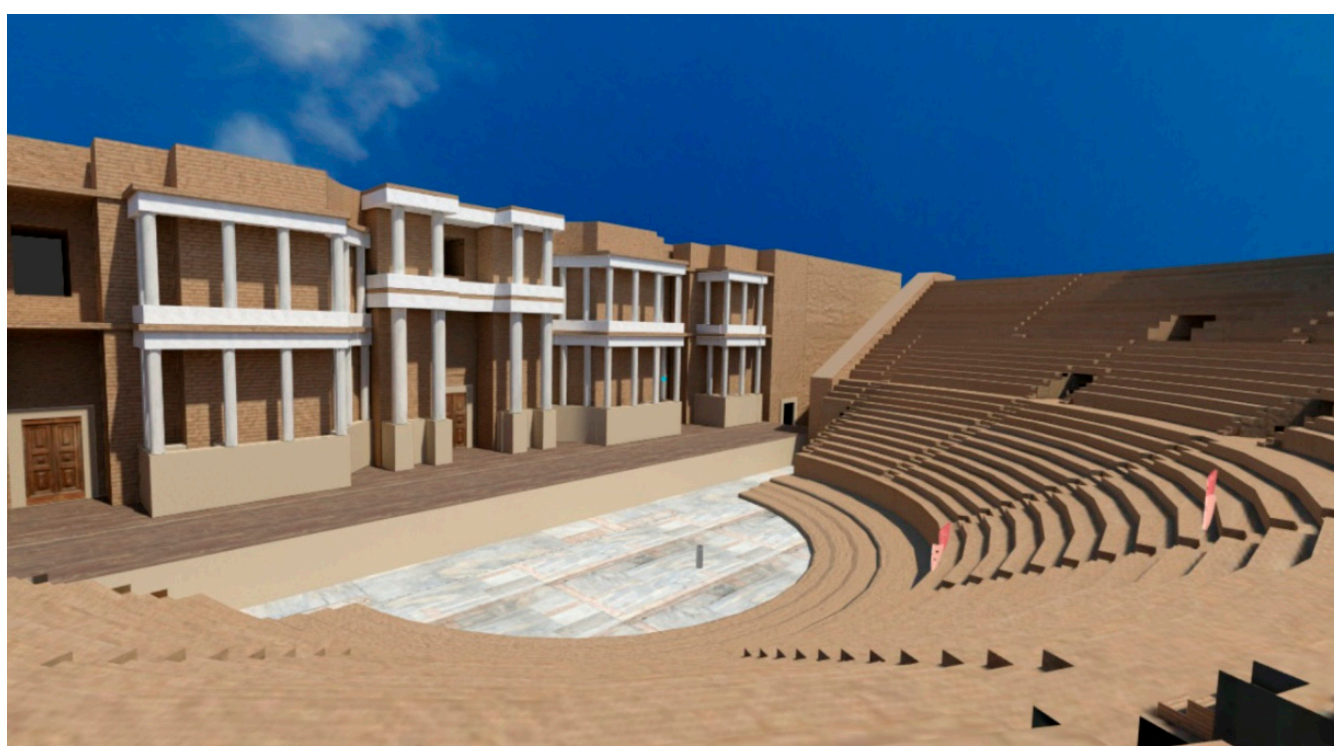

Figure 1. 3D model of the Roman theatre in Gortyna.

For this phase of her work-on which the reliability of the data depended-, she used Odeon Room Acoustics, a software package widely used in the field of architecture and acoustic engineering, which proved useful both in this research and in other research projects devoted to ancient theatres $[13,14]$. In this regard, it is worth remembering that until a few years ago, the acoustic analysis of ancient theatres was limited to measuring and evaluating the physical qualities of sound and its propagation in theatrical spaces. In more recent times, research has been driven towards the interpretation of data obtained through virtual acoustics in order to obtain useful and reliable information to explore the sounds produced in theatrical and performative spaces as well as to hypothesise how they could have been heard and perceived. This qualitative leap in research was possible thanks to the use of software in the field of cultural heritage which, like Odeon Room Acoustics, allows us to consider a series of parameters and also to calculate variations due to weather conditions, the ancient landscape, materials, and the presence (or absence) of an audience.

Having created the 3D model of the monument, which was created with AutoCAD by researchers from the Department of Cultural Heritage of the University of Padua and used for virtual acoustic analysis, the 3D model was imported into Odeon Room Acoustics with a slight modification to the architecture of the theatre in order to simplify the software 
calculations. It was possible to measure the sound impulse containing useful information with the aim of assessing the quality of the acoustics in a virtual environment by applying different parameters. Auralisation was the next step in this phase of the work, that is, the production of audio files capable of reproducing sounds as if they had been recorded in situ: listening to the audio files, elaborated by Paola Calicchia, a researcher in the laboratory at the Institute of Acoustics and Sensors "Orso Mario Corbino" of the National Research Council, made it possible to analyse the quality of the acoustics, also enabling its evaluation through subjective perception. One of the audio files contained a monologue taken from Euripides' Trojans recited by Martina Giovannetti, under the supervision of Cristina Pace.

It is interesting to note that a similar test on the propagation of speech in a public space was also carried out by Susanne Muth and her research team at the Department of Classical Archaeology at Humboldt-Universität zu Berlin for the research project Analog Storage Media-Auralization of Archaeological Spaces. The team used the audio recording of a speech by Cicero against Catiline held in the space of the Roman Forum in front of the temple of Castor (Figure 2) [15]. In the case of this survey, the research group reconstructed the entire area of the temple and the related buildings in 3D in order to evaluate the sound perception of the participants located at different distances using virtual acoustics.

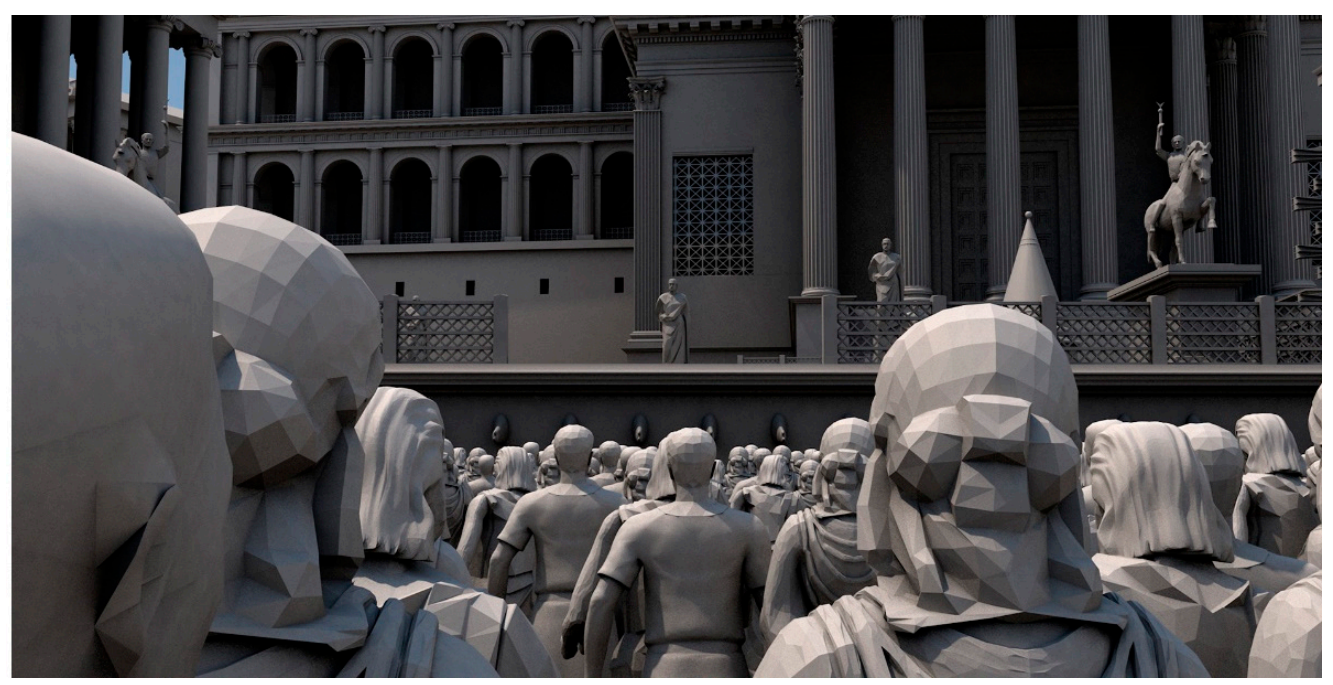

Figure 2. Virtual demonstration "Public Speech on Forum Romanum".

In Manzetti's research, the 3D model and the subsequent virtual acoustic analysis made it possible to hypothesise how the acoustic design of the theatre in Roman times was more suitable for listening to public speeches. In fact, the theatre does not appear suitable for musical competitions, which, according to written sources, were one of the main activities during the Greek festivities dedicated to Apollo Pizio. This data opens up the possibility that in Gortyna, the capital of the Roman provinces of Crete and Cyrenaica, customs more strongly linked to the Roman tradition and to the use of theatres as meeting places for public speeches had been established. Accordingly, the buildings could have been designed and built for political assemblies, having particular acoustic properties able to help speakers effectively convey their arguments. In this case, the architects' major concern may have been to make the acoustics of these places as suitable as possible for listening to the voice.

Cristina Manzetti's study highlighted not only that virtual acoustic analysis could help us to understand what types of activities took place in an ancient theatrical area, revealing habits and customs of the past, but also the importance of acoustics in archaeology for exploring the sound aspects of places that were significant spaces for communication and for sharing sonic experiences [16]. Moreover, virtual acoustic analysis in a 3D environment has also proved to be very useful in archaeological sites that are not completely preserved. This aspect provides new perspectives for research on sonic heritage, taking into consideration 
that acoustic analysis could be used both to acquire data regarding ancient buildings as objective measurements of acoustic parameters and to formulate in-depth and accurate investigations in the archaeological field to integrate traditional methods. In this regard, it should be remembered that both the Greeks and Romans had extensive knowledge of sound and its behaviour in the spaces shared by communities. Moreover, as can be seen from the texts of Aristotle, Aristoxenus, Plutarch, and Vitruvius [17], ancient architects were able to obtain excellent acoustics in important theatres. Despite being outdoors, these buildings boasted an acoustic design that could reach thousands of spectators without amplification, such as the theatre of Epidaurus, which was built in 340 BCE for up to 13,000 spectators.

Another case study related to the survey on sound in archaeological sites is Pamela Jordan's work at the Centre for Ancient Studies and Archaeology at the University of Amsterdam, where the researcher carried out the project Site Sound: Using Acoustics to Analyse Mount Lykaion's Ancient Sanctuary to Zeus (Figure 3) [18]. This research had a focus on sensory archaeology $[19,20]$, a field of research that has greatly expanded the approach and methods for understanding aspects of sensory experience in places significant to ancient communities, especially in terms of their religious function. Moreover, Jordan's research paid particular attention to the field of psychoacoustics and to recent technological advances capable of hypothesising a human response to different sound conditions.

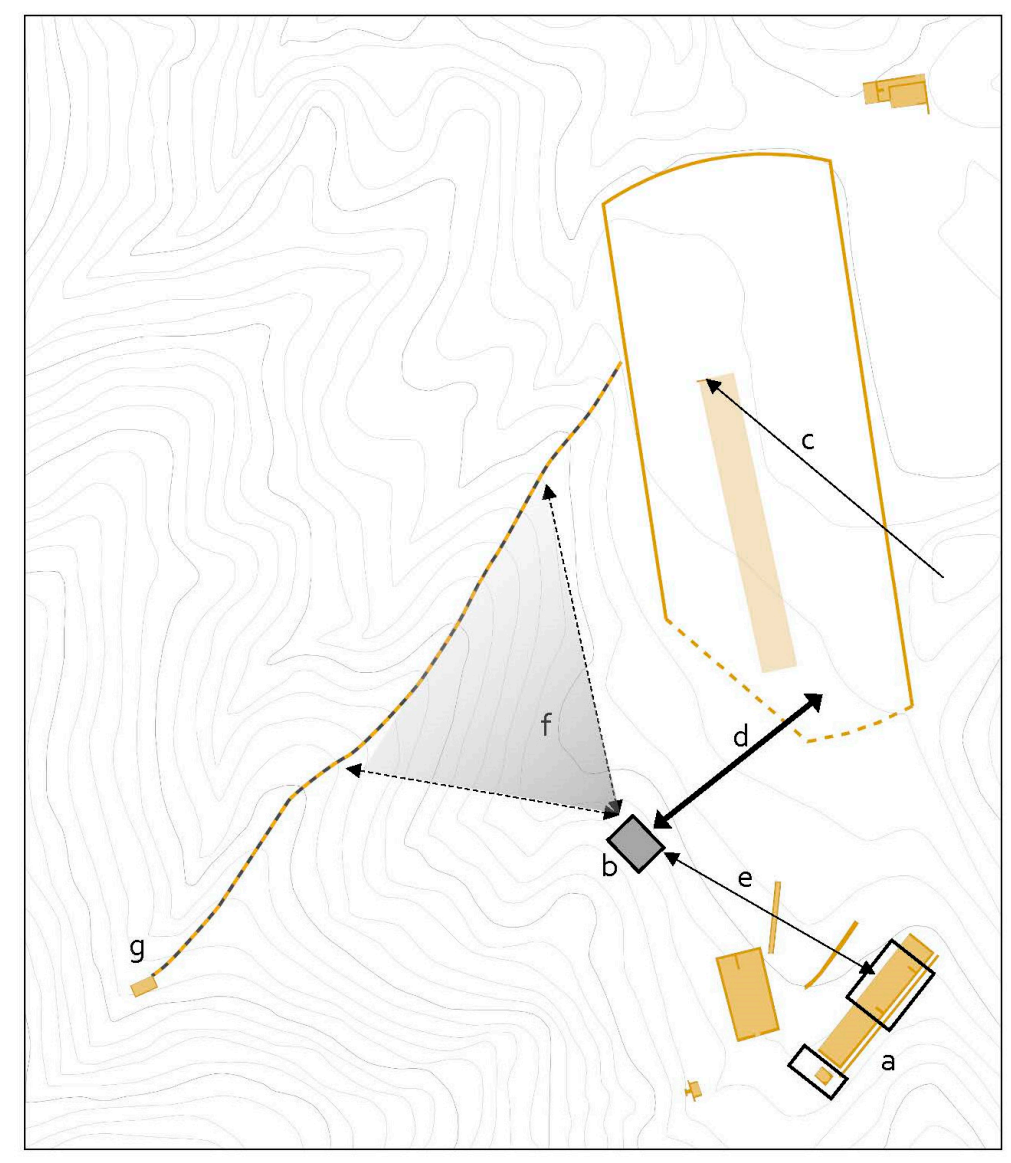

Figure 3. Mount Lykaion's Lower Sanctuary with sonic findings highlighted: (a) Stoa and adjacent building; (b) area of hillside under sonic study; (c) test conducted between the starting blocks (arrow head) and nearby small hilltop; (d) test conducted showing communicative ability between hillside and hippodrome surface; (e) communication possible between hillside and stoa; (f) inconsistent communication possible between possible processional way and hillside under study; and (g) Agno fountain, which is completely sonically isolated from the entire sanctuary. 
From the outset of the project, her investigation at the Hellenic sanctuary of Zeus on Mount Lykaion in Arcadia, Greece, highlighted unusual sound relationships at the site, with the surprising possibility of communication between distant places. The researcher started her study by raising some issues. The first concerned the sound features of the site and the search for indications of possible acoustic awareness of the ancient builders from the placement of the architectural structures. Another issue addressed how the particular sound qualities of a sacred place could have been in relationship with the ritual activities and performances related to the cult of Zeus. In fact, depending on the context, the sound could be a "cultic soundmark" of a particular deity or an essential aspect of the rituals connected to it. This auditory dimension was an essential and common component to all religious, political, and cultural practices in both the Greek and Roman worlds.

Through binaural recordings, psychoacoustic analyses, and, especially, mapping techniques, Jordan's investigation explored the existence of recurring sounds at the site and in the surrounding landscape. Her research used technologies suitable in the field of digital reconstruction of architectural structures and acoustic engineering to test and analyse the sound features of the buildings still preserved at the ancient site. Moreover, through binaural recordings, which allowed for the processing of sound signals for psychoacoustic analysis, she studied sounds in landscape. These disciplinary crossings proved particularly useful for the study of the sanctuary at Mount Lykaion. Indeed, the analysis of the sound features made it possible to recognise some sounds within the sanctuary that were amplified in the architectural structures, crossing or bouncing across the building's remains. The sonic data were related to ritual practices such as processions, musical and dance performances, and banquets performed at the site. Analysing the sonic features and using tools, resources, and technologies, the researcher explored how ancient architects used their acoustics knowledge to enhance the sacred experience in this place of worship.

Jordan's data collection on Mount Lykaion is a work in progress. However, the records have already provided a substantial amount of information that will require further laboratory analysis. According to the researcher, it will be necessary to take into account not only the psychoacoustic observations and the GPS coordinates of the recording locations but also the co-recorded meteorological data, such as wind speed and humidity levels. Furthermore, one of the most useful visual outputs will be the spectrogram, in which some sound data is represented over time, with images that render the audio files into colour-coded data that can be quickly screened and analysed [21].

\section{Discovering Sonic Interactions in an Ancient Theatral Area: The Case of Selinunte}

The knowledge of acoustics of performative spaces in the ancient world appears to reflect a process of gradual change. If, on the one hand, sonic features of a particular space might have directed the choice of suitable places for a greater understanding of the sounds produced in that space, on the other, the development of architecture and the evolution of the form of theatrical spaces seems related to the presence of an ever-increasing number of participants in performances and assemblies, where performers and speakers needed to be clearly understood by the audience. This is one of the aspects covered by the project Stesichoros: The Archaeology of Sound in a Greek City, carried out at the Institute of Heritage Sciences of the National Research Council of Italy.

This research adopted the methods of "archaeoacoustics" or "acoustic archaeology," a research line which is in full development [22]: it is a field that places the study of sonic heritage at the centre of its interest and is aimed at evaluating the sound quality of a space or of a place through auralisation techniques [23]. Research in this area has adopted various approaches that also take into account the relationship between architecture and acoustics and the state of conservation of buildings as well as the analysis of anechoic recordings of music and sounds used in the auralisation processes at archaeological sites [24]. Archaeoacoustics raises a number of challenges concerning the choice of methodology and the approaches to be adopted. For example, the considerable variation in methodological approaches in this research field often derives from how data are collected or produced. 
Archaeoacoustics has always featured computational approaches and modelling; however, when archaeoacoustics is considered within a soundscape research framing, it "can be considered as a contextual experience of spaces and auditory perception as one of the ways in which people made sense of their world" [25]. This research field certainly does not aim to re-enact ancient sounds or listening experiences, nor does it claim to be able to approximate auditory perception in the past: archaeoacoustics aims to carry out investigations on a great variety of places and historical periods, shedding light on sound in the past and providing data for a re-evaluation of archaeological sites thanks to the study of their sonic features $[26,27]$.

In this respect, the Stesichoros project aimed to explore the sonic interactions and the spatial configuration of ancient theatres in their respective landscapes and environment in order to investigate the use of experimental interpretative 3D reconstructions integrating acoustic models as well as auralisation technology in the archaeological field. Indeed, as we have seen, in the last few years, many researchers have devoted their studies to these themes with different methods and results, exploring how digital technologies based on 3D modelling and sound simulations can expand our knowledge on sounds and open up new perspectives on the study and preservation of sound heritage.

In this regard, it cannot be discounted that the sonic aspects of theatral structures might have played an integral and important role in increasing the functionality of these buildings as places of interaction and communication on multiple sensory levels, involving highly visual imagery and dramatic sounds as well as other sensorial experiences. Therefore, the study of the sonic environment of these structures could provide us with new insights on how audiences interacted with soundscapes and landscapes. This is a novel way of approaching and analysing archaeological sites and involves speculating on the soundscape of performative spaces in the past as well as reconstructing how they were experienced.

An example of this approach is the assessment and recovery of the lost intangible heritage in the theatral area at Selinunte, an ancient city recognised today as one of the most important archaeological sites of the Greek period in Italy (Figure 4): from its foundation

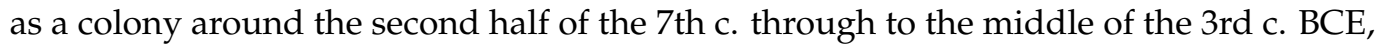
Selinunte enjoyed a prosperous existence as reflected in its notable sanctuaries and temples. The theatral space in Selinunte was chosen for the Stesichoros project survey given that archaeological evidence in this Greek polis in the West highlights some interesting features of this performative structure and its immediate surroundings [28-30]: (1) the proximity of this building to sanctuaries associated with important cults having public character (Demeter and Apollon cults); (2) the presence of instruments and sound tools found in close association with this building, which could have been played during performances and rituals performed in the theatrical area [31-36]. The best example is the aulos from the Temple R; and (3): on the basis of the excavation reports published by the American Archaeological Mission of the Institute of Fine Arts at New York University directed by Clemente Marconi, this theatral structure and its immediate surroundings are of a good standard to allow extensive analysis. Furthermore, there are no restrictions in the access to this monument. The aim was also to investigate whether this building, which is located on the acropolis of the ancient Greek polis, was built in a precise place for its acoustical qualities. Moreover, the research aimed to explore how people experienced this building. We used a range of techniques to investigate the various acoustic properties of this architectural space. To explore and recreate the aural experience, the techniques included the following: 3D modelling to simulate site acoustics using microphones, speakers, and musical performances to assess sounds and evaluate the auditory perception within the theatral area [37]; and experiments using replica of musical instruments as well as sound tools and voices to assess the range of sounds produced and their physical impact. 


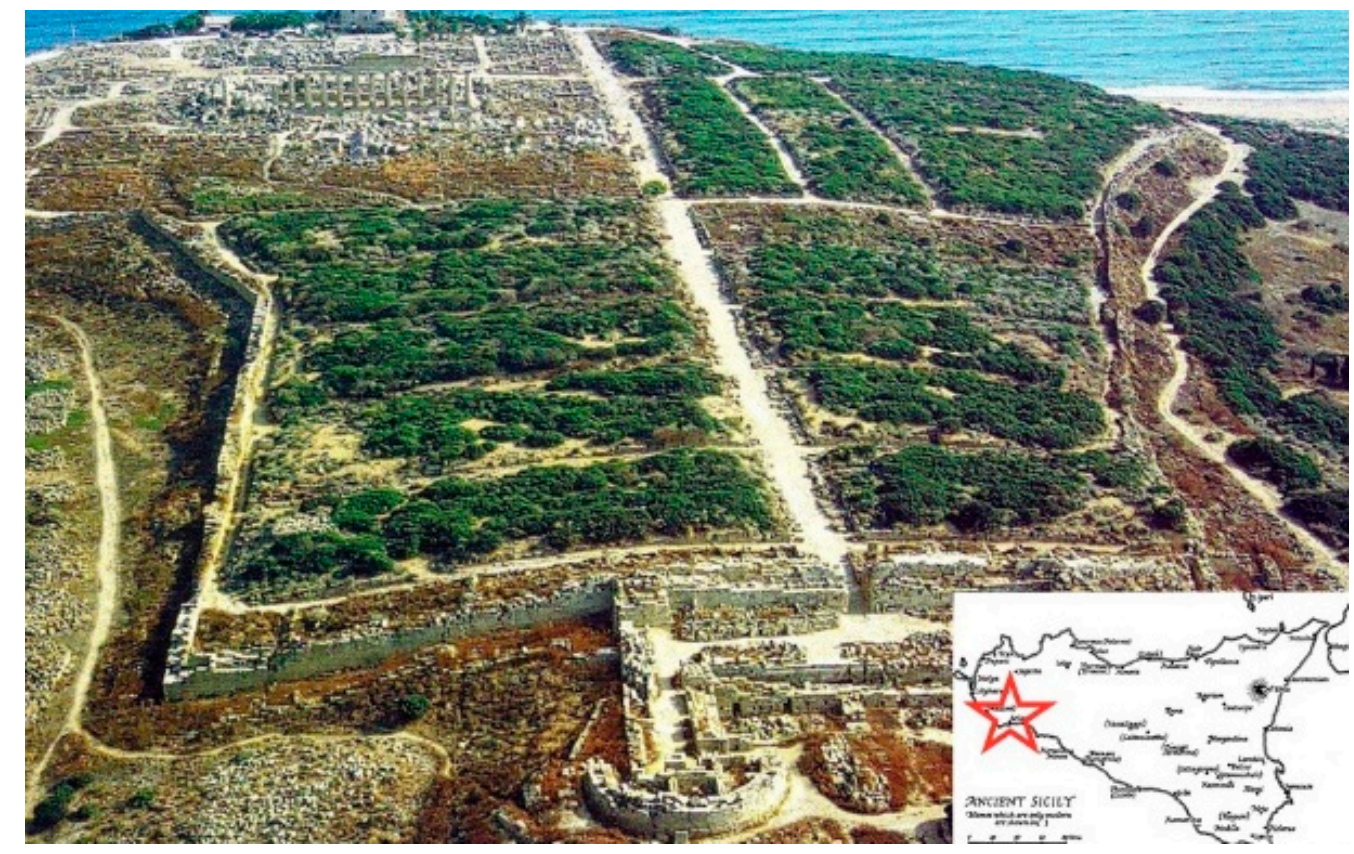

Figure 4. The ancient site of Selinunte in Sicily.

This survey revealed surprising sonic qualities in the theatral area. Given that the theatral structure is not fully preserved, we worked on a 3D model of this theatral building and we used software that is able to calculate acoustic values. Thanks to the development of a virtual application for Oculus Rift, we explored the 3D reconstruction of the theatral area (Figure 5) [31] in the Acropolis of Selinunte and, at the same time, listened to the auralisation from different positions; audio files of the recorded musical performances were also used in our survey. The main aim of this VR application, developed through Unity, is to experience theatres as an ancient listener. Therefore, we developed the VR application through two phases: the first was the 3D modelling and texturing of the theatral area; and the second was the auralisation of an anechoic file of a musical performance from different positions in the 3D model of the theatral structure and its immediate surroundings.

In order to create and to texture the 3D model, we used the software 3D Studio Max 2016. Taking into account that Mental Ray materials could be applied to the surfaces of the 3D models, the renderer was set to NVIDIA Mental Ray given that Mental Ray materials include a kit with pre-set features for certain materials, like stones, which were used in the building of ancient theatres. After new images on the 3D model were mapped, they were exported as .fbx files in order to easily import them into Unity.

The auralisation was performed through the software Odeon Room Acoustics. We used from five to eight audio files, and the files were auralised in different positions in the theatral structure and its related space. The anechoic file was recorded in the laboratory of the Institute of Heritage Science at the CNR, with the collaboration of music makers and professional musicians: their performed short melodies on their aulos, an ancient Greek instrument contemporaneous with the theatral structure in Selinunte, which was reconstructed in different materials. After that, the aulos melodies were recorded in the anechoic room in the laboratory, and the recorded files were imported to the theatre project in Odeon Room Acoustics.

We also used audio files of the recorded natural sounds in the Acropolis in order to recreate the "sonic fabric" of the performative space in Selinunte and to assess the complete sound experience in this theatral area. The Neumann KM 183 omnidirectional microphone was used for recording the impulse responses in nine different receivers located along three directions of the orchestra. The microphone was located in the orchestra along three directions at a constant pitch [38], on the seats, and at a height of $0.8 \mathrm{~m}$. The audio files were 
automatically convolved with the impulse responses recorded by the receivers placed in the theatrical building and space. Given that the impulse response contained information about the architectural features of the theatral structure, it was possible to create a corresponding audio file for the actual sound in a particular position in thetheatral structure.

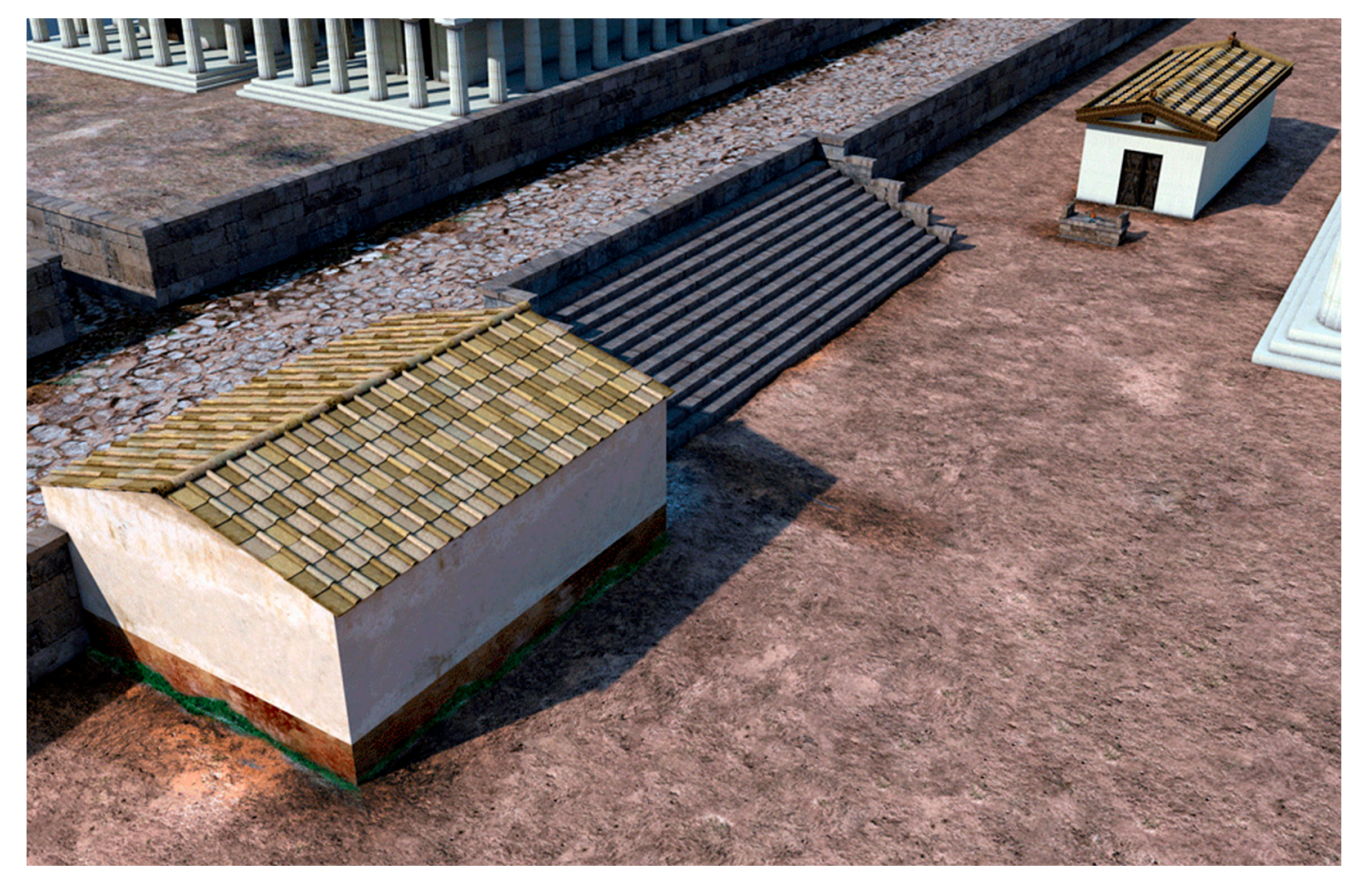

Figure 5. Digital reconstruction of the theatral structure and Temple R in Selinunte. Digital reconstruction: Massimo Limoncelli.

The resulting values obtained through acoustics analysis were necessary for exploring whether, for example, the theatral area was more suitable for talks or more for music (and choral) performances and/or sonic events and to analyse if the acoustics in the theatres and in the immediate surroundings met the criteria for good comprehension of speech or for enjoying music. Moreover, acoustic parameters were useful in understanding the interaction with surrounding sounds from sonic geophony, biophony, and anthropophony.

\section{Conclusions}

From what has emerged from this overview on the study of sonic heritage through digital technology and virtual acoustic analysis, it is clear how the commitment of researchers is proving to be invaluable in overcoming disciplinary barriers and fostering the inclusion of the sound experience in the archaeological field [39]. With their work, they are laying the foundations for a careful study of understanding the past, taking into account acoustic aspects, sound perception, and the behaviour of sound in buildings of the ancient world. Furthermore, whilst their research is providing stimuli for the affirmation of new research fields, such as sensory archaeology [19], auditory archaeology [6], and digital sound studies [12], it is important to underline how their investigations make use of $3 \mathrm{D}$ reconstructions and of the virtual acoustics and spectrograms that have highlighted the non-randomness of the choice of places and spaces for the construction of buildings, performative spaces, and even sacred places. Through the intersection of data and the contextualisation of archaeological evidence as well as the comparison with written and figurative sources, their approaches, methods, and 'disciplinaryhybridization' can allow for an ever-wider knowledge of the function of sound in ancient communities and of sound interaction in the places, spaces, and buildings frequented by the human beings who preceded us. Without doubt, a "soundscape archaeology" approach can enable the 
intersection of sensory sonic concerns with sonic heritage preservation and management, offering new insights for understanding the past [40].

Moreover, information about the architectural structure of ancient performative spaces through acoustics analysis of their 3D models can raise new questions and new hypotheses. An important element to arise from the recent research concerns acoustic properties that can be identified and associated with archaeological spaces: revisiting materials from old excavations as well as analysing discoveries in the context of data from new surveys is providing a hypothesis on their abandonment, perhaps connected to the demand for spaces in which a larger listening audience could be involved.

It is time to focus on all the senses that were involved in the life of ancient people in order to reach a deeper knowledge of the past and of the aural experience in ancient spaces. Performative spaces were characterised by a multitude of activities that engaged all the senses, not only sight. Acoustic properties should be acknowledged and fully integrated into strategies for their management and preservation. This is essential to aid the interpretation of the role of sound in the past and for enhancing how such archaeological spaces were appreciated and understood in the past and, hopefully, how they could be enjoyed in the future.

This approach could create a field of comparative studies of digital heritage while reconfiguring the interdisciplinary foundations of historical acoustemological and soundscape archaeology research as a contextual experience of archaeological spaces. As further studies of soundscapes are undertaken, the everyday life of the past and the sounds that shaped it will enable us to better understand the complex relationship between buildings, performative spaces, social interactions, and environment. Paving a new theoretical path that links digital heritage and acoustic techniques, this approach is expected to produce significant insights into performative spaces and to provide the theoretical basis for exploring the sonic properties of any archaeological space and architectural structure in the future.

Funding: This research was funded by European Commission's MSCA, grant number 792058.

Acknowledgments: I would like to thank the Clemente Marconi, James R. McCredie at the Institute of Fine Arts at New York University, for granting me permission to study the aulos used for sound analysis of this research. I would also like to thank Pamela Jordan, Massimo Limoncelli, Cristina Manzetti, and Susanne Muth (and her research team) for the pictures of digital reconstructions as well as all the musicians and music makers involved in this study.

Conflicts of Interest: The author declare no conflict of interest.

\section{References}

1. Graham, S.; Eve, S.; Morgan, C.; Pantos, A. Hearing the Past. In Seeing the Past with Computers. Experiments with Augmented Reality and Computer Vision in History; Klee, K., Compeau, T., Eds.; University of Michigan Press: Ann Arbor, MI, USA, 2019 ; pp. $224-236$.

2. Blesser, B.; Salter, L.-R. Spaces Speak, Are You Listening? Experiencing Aural Architecture; Massachusetts Institute of Technology: Cambridge, MA, USA, 2007; pp. 67-97.

3. Schulte-Fortkamp, B.; Jordan, P. When Soundscape Meets Architecture. Noise Mapp. 2016, 3, 216-231. [CrossRef]

4. Veitch, J. Soundscape of the Street: Architectural Acoustics in Ostia. In Senses of the Empire: Multisensory Approaches to the Roman Culture; Betts, E., Ed.; Routledge: London, UK; New York, NY, USA, 2017; pp. 54-70.

5. Meineck, P. The Embodied Space: Performance and Visual Cognition at the Fifth Century Athenian Theatre. N. Engl. Class. J. 2012, 39, 3-46.

6. Mills, S. Auditory Archeology. Understanding Sound and Hearing in the Past; Left Coast Press: Walnut Creek, CA, USA, 2014; pp. 53-74.

7. Harrison, S. Composing Archaeology: The Problems of Recrating Heritage in Music. In Music and Heritage. New Perspectives on Place-Making and Sonic Identity; Maloney, L., Schofield, J., Eds.; Routledge: London, UK; New York, NY, USA, 2021 ; pp. 54-70.

8. Primeau, K.E.; Witt, D.E. Soundscape in the Past: Investigating Sound the Landscape Level. J. Archaeol. Sci. 2018, 19, 875-885. [CrossRef]

9. Mattern, S. Sonic Archaeologies. In The Routledge Companion to Sound Studies; Bull, M., Ed.; Routledge: London, UK; New York, NY, USA, 2019; pp. 222-230.

10. Bellia, A.; Pavone, D. Computed Tomography and Handcrafting Processes of an Ancient Musical Instrument. Archeol. E Calc. 2021, 32, 421-447. 
11. Bellia, A. Towards a New Approach in the Study of Ancient Greek Music: Virtual Reconstruction of an Ancient Musical Instrument from Greek Sicily. Digit. Scholarsh. Humanit. 2019, 34, 233-243. [CrossRef]

12. Geoffroy-Schwinden, R.D. Digital Approaches to Historical Acoustemology. In Digital Sound Studies; Lingold, M.C., Mueller, D., Trettien, W., Eds.; Duke University Press: Durham, NC, USA, 2018; pp. 231-249.

13. Manzetti, C. 3D Visibility Analysis as a Mean to Validate Ancient Theatre's Reconstructions. Virtual Archaeol. Rev. 2016, 7, 36-43. [CrossRef]

14. Manzetti, C. The Performance at the Theatre of the Pythion in Gortina, Crete. Virtual Acoustics Analysis as a Support for Interpretation. Open Archaeol. 2019, 5, 434-443. [CrossRef]

15. Holter, E.; Muth, S.; Schwesinger, S. Sounding Out Public Space in Late Republican Rome. In Sound and the Ancient Senses; Butler, S., Nooter, S., Eds.; Routledge: London, UK; New York, NY, USA, 2019; pp. 44-60.

16. Manzetti, M.C.; Papadopoulos, N. Being a Spectators in A Roman Theatre: A VR. Archeol. E Calc. 2021, 32, 437-448.

17. Moretti, J.-C.; Mauduit, C. The Greek Vocabularity of Theatrical Architecture. In The Architecture of the Ancient Greek Theatre; Frederiksen, R., Drougou, S., Gebhard, E., Sokolicek, A., Eds.; University Press: Aarhus, Denmark, 2015; pp. 119-129.

18. Jordan, P. Sound Experience in Archaeology and Field Investigation-An Approach to Mapping Past Activities through Sound at Mount Lykaion's Sanctuary to Zeus. Kleos 2020, 3, 9-30.

19. Derrick, T.J. Sensory Archaeologies. In Senses of the Empire: Multisensory Approaches to the Roman Culture; Betts, E., Ed.; Routledge: London, UK; New York, NY, USA, 2017; pp. 71-85.

20. Day, J. Introduction: Making senses of the past. In Making Senses of the Past: Toward a Sensory Archaeology; Day, J., Ed.; Southern Illinois University Press: Carbondale, IL, USA, 2013; pp. 1-31.

21. Jordan, P. Searching for Ancient Sonic Experience in Present-Day. Archeol. E Calc. 2021, 32, 419-436.

22. Scarre, C.; Graeme, L. Archaeoacoustics; McDonald Institute for Archaeological Research: Cambridge, UK, 2006.

23. Schofield, J. The Archaeology of Sound and Music. World Archaeol. 2014, 46, 289-291. [CrossRef]

24. Blake, E.C.; Cross, I. The Acoustic and Auditory Contexts of Human Behavior. Curr. Anthropol. 2015, 56, 81-103. [CrossRef]

25. Suárez, R.; Alonso, A.; Sendra, J.J. Archaeoacoustics of Intangible Cultural Heritage. J. Cult. Herit. 2016, 19, 567-572. [CrossRef]

26. Eneix, L.C. Archaeoacoustics II. The Archaeology of Sound; OTS Foundation: Myakka, FL, USA, 2016.

27. Eneix, L.C.; Ragussa, M. Archaeoacoustics III. The Archaeology of Sound; OTS Foundation: Myakka, FL, USA, 2018.

28. Marconi, C. Nuovi dati sui culti del settore meridionale del grande santuario urbano a Selinus. Sicil. Antiq. 2013, $10,263-271$.

29. Bellia, A. Performative Aspects of Music in Sacred Contexts of the Western Greeks. In The Study of Musical Performance in Antiquity: Archaeology and Written Sources; Garcia-Ventura, A., Tavolieri, C., Verderame, L., Eds.; Cambridge Scholars Publishing: Newcastle upon Tyne, UK, 2018; pp. 155-173.

30. Marconi, C. A New Bone Aulos from Selinus: Music and Spectacle in the Main Urban Sanctuary of a Greek Colony in the West. In Musica, Culti E Riti Dei Greci d'Occidente; Bellia, A., Ed.; Istituti Editoriali E Poligrafici Internazionali: Pisa/Rome, Italy, 2014; pp. 105-116.

31. Marconi, C.; Scahill, D. The "South Building" in the Main Urban Sanctuary of Selinus: A Theatral Structure? In The Architecture of the Ancient Greek Theatre; Frederiksen, R., Drougou, S., Gebhard, E., Sokolicek, A., Eds.; University Press: Aarhus, Denmark, 2015; pp. 281-294.

32. Polacco, L. Il Teatro Di Dioniso Eleuterio Ad Atene; L'Erma di Bretschneider: Rome, Italy, 1990.

33. Nielsen, I. Cultic Theatres and Ritual Drama. A Study in Regional Development and Religious Interchange between East and West in Antiquity; University Press: Aarhus, Denmark, 2002.

34. Hollinshead, M.B. Monumental Steps and the Shaping of Ceremony. In Architecture of the Sacred; Wescoat, B.D., Ousterhout, R.G., Eds.; University Press: Cambridge, UK, 2012; pp. 27-65.

35. Sokolicek, A. Form and Function of the Earliest Greek Theatres. In The Architecture of the Ancient Greek Theatre; Frederiksen, R., Drougou, S., Gebhard, E., Sokolicek, A., Eds.; University Press: Aarhus, Denmark, 2015; pp. 97-104.

36. Bellia, A. Relation of Music to Cultural Identity in the Colonies of West Greece. J. Musicol. 2015, 1, 46-59.

37. Rainio, R.; Lahelma, A.; Äikäs, T.; Lassfolk, K.; Okkonen, J. Acoustic Measurements and Digital Image Processing Suggest a Link between Sound Rituals and Sacred Sites in Northern Finland. J. Archaeol. Method Theory 2018, 25, 453-474. [CrossRef]

38. Farina, A.; Tronchin, L. 3D Sound Characterisation in Theatres Employing Microphone Arrays. Acta Acust. 2013, 99, 118-125. [CrossRef]

39. Kolltveit, G.; Rainio, R. The Archaeology of Sound, Acoustics \& Music: Studies in Honour of Cajsa, S. Lund; Ekho Verlag: Berlin, Germany, 2020.

40. Primeau, K.E. Current Trends in Archaeoacoustics. Available online: https://www.academia.edu/46920574/Current_Trends_in_ Archaeoacoustics (accessed on 30 August 2021). 